Chicago-Kent College of Law

Scholarly Commons @ IIT Chicago-Kent College of Law

All Faculty Scholarship

Faculty Scholarship

January 2007

\title{
Competition Law and the WTO: Rethinking the Relationship
}

David J. Gerber

IIT Chicago-Kent College of Law, dgerber@kentlaw.iit.edu

Follow this and additional works at: https://scholarship.kentlaw.iit.edu/fac_schol

Part of the International Economics Commons, and the International Trade Law Commons

\section{Recommended Citation}

David J. Gerber, Competition Law and the WTO: Rethinking the Relationship, 10 J. Int'I Econ. L. 707 (2007).

Available at: https://scholarship.kentlaw.iit.edu/fac_schol/220

This Article is brought to you for free and open access by the Faculty Scholarship at Scholarly Commons @ IIT Chicago-Kent College of Law. It has been accepted for inclusion in All Faculty Scholarship by an authorized administrator of Scholarly Commons @ IIT Chicago-Kent College of Law. For more information, please contact jwenger@kentlaw.iit.edu, ebarney@kentlaw.iit.edu. 


\title{
COMPETITION LAW AND THE WTO: RETHINKING THE RELATIONSHIP
}

\author{
David f. Gerber*
}

\begin{abstract}
This essay identifies obstacles to the inclusion of a competition law regime in the WTO and suggests changes that are likely to be necessary if competition law is to become an effective part of the WTO. Two obstacles have impeded inclusion of competition law in the WTO's legal regime and are likely to continue to do so. They are (i) a lack of confidence that the norms, practices and procedures of the WTO rest on a robust conception of community and (ii) uncertainty and concern about what form of competition law might be included and what its role in the WTO would be. In order to reduce the first of these obstacles, the institutions and members of the WTO will need to develop a conception of community that engenders widespread confidence in the WTO's basic modes of operation. Eliminating the second obstacle would require clarification of the kind of competition law that would be acceptable within the WTO, and this, in turn, is likely to require development of a form of competition law that is specifically designed for the WTO and that can elicit the long-term support of all categories of members. The essay suggests that the competition law issue is intricately interwoven with the future of the WTO. The changes that would be necessary to introduce and successfully implement competition law in the WTO are to a large extent the same as those that the institution will need to make if it is to enrich its role as an institution.
\end{abstract}

\section{INTRODUCTION}

Prior to the creation of the WTO there were two serious attempts to create a comprehensive normative framework for international economic relations one at the Geneva International Economic Conference in 1927 and another following the Second World War. In both, competition (or 'antitrust') law was often portrayed as an important part of the proposed framework. If such a framework were to be effective, so the argument went, it would have to include

* Distinguished Professor of Law in Chicago-Kent College of Law, Chicago, Illinois, Email: Dgerber@kentlaw.edu. The author would like to thank Sungjoon Cho for his comments on an earlier draft of this article and for his many insights into the issues treated here. 
not only norms governing the conduct of states, but also norms governing the conduct of private institutions that had sufficient power to impede international trade and competition. Private institutions were seen as posing threats to international competition that were potentially as serious as those posed by governments. Despite this history and the logic of the policy argument, competition law was not included in the WTO, and efforts to place it on the WTO's negotiating agenda have failed. Why the changed perspective and what does the change suggest about the WTO's path ahead? What obstacles stand in the way of including competition law in the WTO and making it effective? And how might competition law contribute to developing the effectiveness of the WTO? This essay addresses those questions.

The pre-WTO efforts at economic norm-making on a global scale were based on a conception of the international economy as a shared resource in which norms could be expected to enhance the value of that resource for all participants. In this sense, conceptions of community were the basis for the normative plans. To be sure, these visions of community were aspirational. In 1927, they were based more on hopes for the future than on existing realities, and post-Second World War efforts were driven by US visions of the future that were not always shared by others. Nevertheless, competition law was considered important in both efforts. ${ }^{1}$

In the context of the WTO, a narrower vision of international economic relations has prevailed. In it, the focus is on the actions of states that impede trade and competition, while the actions of private institutions that may have similar effects have been curiously privileged. From this perspective, the WTO's mission appears unbalanced, treating that part of the problem whose treatment best serves US and European interests, but neglecting the issues whose treatment would weigh most heavily on US and European companies, given that they are most likely to have the economic power necessary to engage in global-level anticompetitive conduct.

The WTO's tenth anniversary presents a valuable and timely opportunity to reflect on the relationship between competition law and the WTO. Although there has been much discussion of the issue of competition law in the WTO, most writing on the subject was done several years ago and thus does not reflect recent experience. Moreover, competition law raises fundamental issues about the operation and role of the WTO that have marred its successes during its first decade and that are thus at the forefront of current discussions.

This essay makes three basic claims. The first is that two main obstacles have impeded inclusion of competition law in the WTO's legal regime and

\footnotetext{
${ }^{1}$ For the Geneva conference, see Wallace McClure, "National Economic Independence in the Light of the International Economic Conference', 27 American Journal of International Law 668 (1927). The Havana charter episode is discussed in Susan Ariel Aaronson, Trade and the Amcrican Dream (Lexington: Kenrucky UP, 1996) and William Diebold, Jr., 'The End of the I.T.O.', Essays in International Finance, 16, (1952) Princeton: Princeton University.
} 
that these are likely to continue to inhibit establishment of an effective competition law in the WTO. They are (i) a lack of confidence that the norms, practices and procedures of the WTO rest on a robust conception of community and (ii) uncertainty and concern about what form of competition law might be included and what its role in the WTO would be.

A second claim is that competition law could become an effective part of the WTO, but only if and to the extent that the above-mentioned obstacles can be eliminated or significantly reduced. In order to reduce the first of these obstacles, the institutions and members of the WTO will need to develop a conception of community that engenders widespread confidence in the WTO's basic modes of operation. There has long been talk about a 'community of nations', but few would argue that the current operations of the WTO rest on a robust concept of community. ${ }^{2}$ In its current form, the WTO operates primarily as a venue for negotiating and transferring access rights to the markets of member countries, ${ }^{3}$ but introducing competition law into the WTO would require a different or at least additional conception of the WTO's goals and operations. Eliminating the second obstacle would require clarification of the kind of competition law that would be acceptable within the WTO, and this, in turn, is likely to require development of a form of competition law that is specifically designed for the WTO and that can elicit the long-term support of all categories of members.

The third basic claim is that the competition law issue is intricately interwoven with the future of the WTO. It points, for example, to obstacles and opportunities that face the WTO as an institution. It can also serve as a metric of the WTO's progress toward a more compelling conception of community. The changes that would be necessary to introduce and successfully implement competition law in the WTO are to a large extent the same as those that the institution will need to make if it is to enrich its role as an institution. Finally, competition law can also serve as an incentive for WTO members to work toward those changes.

\section{COMPETITION LAW IN THE WTO: IDENTIFYING THE OBSTACLES}

One way of assessing a future role for competition law. in the WTO is to examine the obstacles that have impeded its inclusion so far. I will here focus on the most recent rejection of competition law - i.e. the failed attempt to

2 Sungioon Cho has elaborated the concept of 'community' in relation to the WTO concept very effectively and with excellent insights, and I am indebted to him for discussing the topic with me and enriching my understanding of the issue. See Sungioon Cho, "The WTO's Gemeinschaft'; 56 Alabama Law Review 483 (2004).

${ }^{3}$ The canonical treacment of the WTO's creation, objectives and intended roles is discussed in John H. Jackson, The World Trading System: Law and Policy of International Ecoriomic Relations, 2nd ed. (Cambridge, MIT Press, 1997). For detailed discussion of current patterns of operation, see Sungioon Cho, 'Doha's Development'; 24 Berkeley Journal of International Law (forthcoming, 2007). 
include it on the negotiating agenda for the Doha round of negotiations. ${ }^{4}$ The story has many dimensions, including, in particular, political ones, but my concern here is only with the basic outlines of legal and institutional development.

The effort to include competition law in the WTO began to take shape in the mid-1990s under the leadership of the European Union. Arguing that competition law belonged in the WTO because private distortions of competition were a significant problem, key leaders in the European Commission sought to put it on the agenda for the impending negotiations. In preparation for this possibility, the WTO appointed Frederic Jenny, a well-known French economist and vice president of the French Competition Council, to conduct studies of its feasibility. Jenny gathered support for such a move and became relatively confident that significant support existed. ${ }^{5}$ Nevertheless, the effort to put competition law on the agenda failed, when both the United States and a large group of developing countries declined to support it.

Although many factors were involved in this failure, lack of confidence in the norms and procedures of the WTO was a central theme. Each resistant group doubted that the WTO would make decisions on the basis of adequate respect for that group's interests. In the United States, there was fear that a competition law in the WTO might be directed primarily at large multinational firms, many of which are US-based. US government officials were not prepared to accept such a threat to US interests. ${ }^{6}$ Developing countries also generally showed little confidence that a competition law regime in the WTO would be implemented in ways that reflected a broad set of Member State interests. ${ }^{7}$ Many feared that its main effect would be to assist US, European and Japanese firms in getting access to their markets and raw materials. The suspicion was not without foundation. The US had aggressively used antitrust for this purpose in the not too distant past (e.g. Japan in the early 1990s) and market access was a focus of much US and European energy in the WTO: Growing disenchantment with the results of the TRIPS agreement undoubtedly played a significant role in engendering distrust of competition law, because developing countries often believed

${ }^{4}$ Philip Marsden describes the sequence of events in Philip Marsden, $A$ Competition Policy for the WTO, (London: Cameron May, 2003) 55-66.

'For Jenny's view of these issues, see, e.g. Frederic Jenny, 'Cartels and Collusion in Developing Countries: Lessons from Empirical Evidence', 29 World Competition Law Review 109 (2006). Rob Anderson, a WTO official with experience in the Canadian comperition authority, also played an important role in this process.

- See, e.g. Joel L. Klein, 'Anticipating the Millenium: International Antitrust Enforcement at the End of the Twentieth Century' (Speech presented at the Fordham Corporate Law Institute, 24th Annual Conference on International Law and Policy on 9 November 2000).

' For a recent discussion of the positions of developing countries in this debate, see Aditya Bhattacharjea, 'The Case for a Multilateral Agreement on Competition Policy: A Developing Country Perspective', 9 Journal of International Economic Law 293 (2006). 
that the seemingly neutral provisions of that agreement had been applied in ways that gave undue and unanticipated advantages to developed country interests at the expense of developing countries.

The common thread linking these two rejections was a lack of confidence in the processes that create, shape and implement norms in the WTO. For different reasons, the two groups were unwilling to entrust their interests to the WTO in the context of competition law, because they did not believe that those interests would be adequately protected. In effect, neither group had confidence that the WTO was likely to operate on the basis of a robust conception of community.

Confusion and uncertainty about the kind of competition law that might be included in the WTO added to this distrust. Developing countries have generally had little, if any, experience with competition law, and this in itself made them uncertain and cautious about what such a law might contain. Moreover, there was little doubt that the US would demand an antitrust law modeled on its own antitrust thinking and that this model was likely to dominate any discussion of what form competition law should take. For many developing countries, however, this US model remained suspect. ${ }^{8}$ There were fears, for example, that it might not only coerce access to markets, as noted above, but also inhibit cooperative responses from domestic companies. The US conception of antitrust law (and increasingly also the EUs conception of competition law) seemed more likely to affect agreements among producers in developing countries than the unilateral conduct of multinationals, and this seemed to many to represent an imbalance designed to favor developed country interests.

For American observers and officials, on the other hand, there was fear that whatever form competition law might take in the WTO, it might be implemented in ways that harmed US interests. For example, one concern was that it would be ineffective and thereby 'water down' the more rigorous treatment of competition law in the US and Europe. ${ }^{9}$ Others feared a different result - that competition law might be used to target US multinational corporations. Finally, there is widespread confidence in US antitrust circles that US antitrust is simply the 'right' form for competition law, not only for the US, but generally. ${ }^{10}$ As a result, there is significant resistance to deviating from that form. The current US antitrust orthodoxy relies heavily on economic analysis, specifically neo-classical economics, to provide its norms and to apply them. It emphasizes the harms that result

Ibid at 316-23.

${ }^{9}$ See e.g. Diane P. Wood, 'The Internationalization of Antitrust Law: Options for the Future', 44 DePaul Law Review 1289 (1995), at 1294.

${ }^{10} \mathrm{See}$, e.g. Ky P. Ewing, Competition Rules for the 21st Century: Principles from America's Experience (The Hague: Kluwer Law International, 2003). For discussion of this view of the 'correctness' of US antirrust law, see David J. Gerber, 'Competition', in Peter Cane and Mark Tushnet (eds), The Oxford Handbook of Legal Studies (Oxford: Oxford UP, 2004) 510. 
from agreements among competitors, but pays significantly less attention to potential harms from unilateral conduct.

\section{COMMUNITY AND THE POTENTIAL ROLE OF COMPETITION LAW IN} THE WTO

The failure of these efforts to include competition law within the WTO signals the need to reassess and reconceive the relationship between the WTO and competition law. The two obstacles identified above are likely to prevent effective inclusion of competition law in the WTO, unless there is serious rethinking of fundamental issues in that relationship. This section outlines some of the elements that may be of value in such an effort.

In this rethinking, it is important to identify three components of current thinking that impede development of an effective relationship between competition law and the WTO. One is the 'eternal failure' image. Some commentators have claimed that the failure of previous attempts to achieve a transnational competition law means that it cannot succeed now (or, perhaps, ever). Such a claim is at best unpersuasive. Past failures of efforts to develop a transnational competition law may highlight the difficulties faced by current attempts in the WTO, but they can do no more than that. The current siruation differs in often extensive ways from the situations in which prior attempts have been made, and thus there is no basis for assuming that the difficulties and outcomes of prior efforts will be repeated in the future. Moreover, the kinds of changes suggested in this essay are feasible and would, if pursued, further distinguish future situations from past failures. That such 'doomed to failure' claims are made by serious scholars suggests the degree of mystification surrounding the issue and underscores the need for rigorous rethinking of the issues involved.

A second image that may constrain rethinking on this issue assumes that competition law must serve 'trade' interests. Discussions of competition law in the WTO often assume that the WTO's objective is to protect international trade and that competition law must, therefore, serve trade objectives. Framed this way, the existing obstacles to effective inclusion of competition law are likely to remain. It is precisely this image of competition law as a trade tool of developed countries that concerns developing countries. The fear that competition law would serve primarily to increase access by US, European and Japanese firms to developing country markets has fueled resistance to the competition law project. If competition law were seen not as subservient to trade law, but rather as coequal with trade law, the path forward would be more inviting, and progress would be more promising. In this view, competition law and trade law operate as equally legitimate and institutionally supported legal regimes, each with its own objectives and institutional and intellectual tools. They are related to each other by the objective of protecting the competitive process on the 
transnational level. Trade law treats the constraints placed on global competition by governments, while competition law treats the impediments created by private firms. They operate in tandem.

Third, and related, is the assumption that competition law would have to be conceived and implemented in the same way that current WTO law is conceived and implemented - i.e. that it must operate in the same ways as the existing trade law regime operates. This assumption tends to block points of entry for competition law into the WTO: With certain exceptions, ${ }^{11}$ the current WTO system is concerned with tights, basically market access rights: In it, states bargain with other states over the degree to which individual states will relinquish their rights to exclude particular products or business activities from their territory. Rights to exclude are the fulcrum, and the enforcement mechanism is based on the denial of access rights by one state against another for its failure to honor obligations regarding its use of such access rights.

Competition law represents a fundamentally different kind of legal regime. In it, the issue is conduct standards. These may be shaped by a variety of goals, but they must be generally applicable in order for a competition law regime to achieve legitimacy and political support. In contrast to the current regime of market access negotiations, a competition law regime is not amenable to bargaining over specific benefits and costs to individual members. The assumption that competition law would have to 'fit' into the current trade law regime easily leads, therefore, to the conclusion that a competition law project must be rejected as inappropriate for the WTO. There is, however, no necessary basis for assuming that competition law must operate according to the same principles as those on which the WTO currently operates.

Identifying these constraints on current thinking underscores the need to rethink the relationship between competition law and the WTO. It highlights the differences between competition law and the traditional concerns of the WTO and suggests that inclusion and operation of a competition law regime in the WTO calls for a revised perspective on the modes of operation of that organization.

\section{TAKING COMMUNITY SERIOUSLY}

A full analysis of the many issues involved in creating the conditions for an effective competition law in the WTO is beyond the scope of this brief essay. Here I merely identify two factors that are likely to be critical to the success of such an enterprise. The first involves the WTO's mode of operation, and

${ }^{11}$ For insightful discussion of recent developments in this area, see, e.g. Thomas Cottier, 'From Progressive Liberalization to Progressive Regulation', 9 Journal of International Economic Law 779 (2006). 
the second involves the form of competition law that might be considered for inclusion in the WTO.

If, as I argue above, lack of confidence in the basic mode of operation of the WTO has been an obstacle to introducing competition law into the WTO, then changing the perceptions that underlie that lack of confidence is likely to be a necessary condition for including competition law in the WTO. Accordingly, a primary objective must be to develop norms and procedures that are perceived as consistent with a 'community-based' image of the WTO. The issue is whether the WTO can take the idea of community seriously and give it operational force.

\section{A. Decisional factors}

In considering that issue, it is necessary to take into account the context in which decisions about competition law will be made. ${ }^{12}$ Curiously, discussions about introducing competition law into the WTO often overlook the basic fact that the introduction of such a law will depend on voluntary, political decisions by the Member States acting in their own interests. There is no current institutional mechanism for obligating members to accept such provisions or for pressuring or shaping their decisions on this issue. Competition law can be expected to affect many interests in most, if not all, Member States, and thus the introduction of a competition law regime will require high-level political support. The issue is far too large and too sensitive to be entrusted to 'experts' or to be pushed through 'under the radar'.

This decisional context means that the issue has to be located at the systemic level. It necessarily involves perceptions of how the WTO's institutions operate and cannot be framed as a narrow and technical issue. It requires persuading Member States to support a rather vague normative project that could have very broad ranging consequences. A focus on the basic modes of operation of the WTO is thus politically imperative for framing a conception of community that could support the introduction of competition law into the WTO. It is not only a conceptual and perceptual issue, but also a highly practical one that requires convincing skeptical political leaders to accept a controversial project that is likely to have consequences that are not only significant and potentially menacing, but also difficult to predict.

Some have suggested that there is little point in thinking about 'community' in the context of the WTO until and unless members routinely adhere to the commitments they have already made. In this view, 'community' must be seen as a distant ideal because there is insufficient cooperation with existing WTO obligations to justify expecting higher levels of commitment.

12 For discussion of related issues, see Mitsuo Matsushita, 'Basic Principles of the WTO and the Role of Competition Policy', 3 Washington University Global Studies Law Review 303 (2004). 
The degree to which a member fulfills current WTO obligations may indicate its willingness to accept additional obligations, but its relevance for moving toward a greater degree of 'community' should not be overstated. Willingness to fulfill obligations is associated with the perceived legitimacy of the processes by which the obligations are incurred. A deeper and broader conception of community is likely, therefore, to increase the willingness of states to fulfill their obligations. Viewed from this perspective, the argument that a deeper conception of community is not yer 'ripe' is inapposite and should not block the path of competition law development.

\section{B. Competition law and a WTO-based concept of community}

In considering the development of a more 'community-based' conception of the WTO that could support an effective competition law regime, three factors seem likely to be central. ${ }^{13}$ All relate to interests and incentives. This conception of 'community' is more objective than some commentators have proposed. It casts 'community' as a dynamic process rooted in and driven by the interplay of interests and incentives. Although major writers consider factors such as empathy to be an important element in building a more community-based WTO, ${ }^{14}$ this largely subjective conception has limitations under current conditions. It can be of value in many cases, but a more objective conception of community that is based on interests and incentives aligns more closely with the current realities of the WTO and thus may be more persuasive for those skeptical of including competition law in the WTO.

\section{Respecting interests}

One dimension of an enriched version of community calls for increased opportunities for members to influence WTO decisions. It would require that members be heard in all situations where their interests may be affected, and it would require that with regard to any decision, WTO decision makers give significant weight to the interests of all categories of members that might be significantly effected by that decision. The experience of developing countries in recent years has led many to question whether their views and interests are given this type of respect in the current operations of the WTO ${ }^{15}$ Disparities in power and influence within the WTO tend to increase sensitivity on this issue among those with less power. If members believe that

${ }^{13}$ This discussion is directed specifically to the concept of community as it relates to the competition law issue. A fuller elaboration of the concept is beyond the scope of this article. In addition to Sungioon Cho's valuable work, see Steven Brint, 'Gemeinschaft Revisited: A Critique and Reconstruction of the Community Concept'; 19 Sociological Theory 1 (2001).

${ }^{14}$ See, e.g. Cho, above n 2, at 519-23 (advocating a conception of community in which empathy plays an important role).

${ }^{15}$ For in-depth discussion of these kinds of 'global balance' issues, see Ethan B. Kapstein, Economic fustice in an Unfair World (Princeton: Princeton UP, 2006) and Frank J. Garcia, Trade, Inequality, and fustice: Toward a Liberal Theory of fust Trade (Ardsley, NY: Transnational Publishers, 2003), 
their interests will be taken into account and given weight in the decisionmaking process, they are more likely to accept the potential costs that may be involved in the operation of a competition law regime.

Meeting this objective will require modification of some WTO decisionmaking procedures and patterns of operation. In the context of competition law, however, such modifications are critical because, in contrast to the current trade-based regime, competition law involves conduct standards and procedures that are intended to be the same for all participants and to apply equally to all participants. ${ }^{16}$ Members are not likely to support such a normative regime unless they are convinced that they have the opportunity, singly or with others, to play significant roles in developing and applying these kinds of general conduct norms.

\section{Aligning interests and incentives}

A second component of this enriched image of 'community' involves the alignment of interests. Members must be convinced that their interests are generally aligned with the interests of other members over the range of decisions affecting them. This does not mean, of course, that the interests must be identical or even always similar. It does mean that non-transitory conflicts among significant and stable groups of members over major issues are likely to make a competition law regime unacceptable and unworkable. For example, as long as members perceive major and non-transitory conflicts between the interests and objectives of developed and developing country members, many developing countries will find it difficult to accept a competition law regime, not least because developed countries are markedly better equipped to use institutional rules and procedures to their advantage.

In the current WTO regime, such long-standing and well-entrenched conflicts have become a significant impediment to effective development of the WTO's institutions. Developing country disappointment over the implementation of the TRIPS agreement has been a central motif in discussions of the WTO for several years. ${ }^{17}$ Such conflicts can be expected to be even greater in the competition law context, however, because, as noted, competition law involves the development and application of generalized conduct standards, and thus it depends for its legitimacy on confidence in the processes by which decisions are made. Major and non-transitory conflicts, especially those involving significant power disparities, would generate distrust in those decision making processes.

10 Joseph Weiler discusses related issues of legitinacy with penetrating insight in Joseph H.H.Weiler, 'The Rule of Lawyers and the Ethos of Diplomats: Some Reflections on the Internal and External Legitimacy of WTO Dispute Settlement', 35 Journal of World Trade 191 (2001).

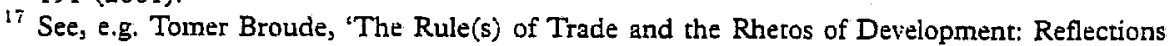
on the Functional and Aspirational Legitimacy of the WTO', 45 Columbia Journal of Transnational Law 221 (2006). 


\section{Shared interests}

Although attainment of the goals noted above-i.e. generalized respect for the interests of all groups and reasonable alignment of interest-based incentives - is likely to be a necessary condition for the establishment of an effective competition law regime in the WTO, it will probably not be a sufficient condition. This is likely to require, in addition, a widespread perception that the WTO is operating and will continue to operate on the basis of 'shared interests'. This means that members must perceive their interests to be associated and interwoven with goals, projects or processes that they share with the other members. Where interests are shared in this sense, each participant expects to derive benefits for itself from the combined actions or decisions of the others in the group. Those decisions and actions may involve, for example, the success of a set of development goals or the creation of better decision-making processes. The interests are shared in the sense that each participant derives benefit from the same source as the other participants, and thus the costs of participation of each are tied to the incentives and benefits of the others. This form of shared interests can generate confidence in decision making processes, support for institutional decisions and impetus for contributions to shared projects.

Two main types of shared interests are likely to be prominent. One is political and institutional. The perception that the interests of all members are closely associated with the stability; effectiveness and development of particular WTO procedures such as the dispute resolution process may, for example, provide incentives for firms to factor this shared institutional interest into their own decisions. Another category of shared interests is economic. ${ }^{18}$ For example, to the extent that members identify their interests with the goal of reducing obstacles to economic development in developing countries, this provides incentives for them to incur costs in the operation of a competition law regime in the expectation that such a regime would help reduce such obstacles and thus provide (shared) benefits for each that exceed those costs.

If members of the WTO were confident that the WTO would operate in ways that would respect, promote and develop the interests just outlined, this would provide a solid basis for introducing competition law into the WTO framework. It would reduce or eliminate most of the current obstacles to the competition law project. There is, however, one additional obstacle that stands in the way of introducing competition law and making it effective. I refer to uncertainty about the concept of competition law itself and expectations about the consequences of introducing whatever form of competition law might be proposed.

18 For discussion of some of the economic and political issues involved, see, e.g. Bernard M. Hoekman; 'Economic Development, Competition Policy and the World Trade Organization; 37 Journal of World Trade 1 (2003). 


\section{COMPETITION LAW: PERCEPTION AND ILLUSIONS}

Discussions of the potential role of competition law in the WTO often proceed as if the meaning of 'competition law' were self-evident. They often imply that there is only one kind of competition law and that everyone knows what the term means. Few address the question 'what kind of competition law would be introduced and what would the probable consequences of its operation be?' For those who wish to include competition law in the WTO, this strategy is attractive, not least because it projects a relatively straightforward and low-cost path of negotiation. If there is no need to talk about the content of competition law, then many fewer decisions need to be negotiated. Many assume that the best path is, therefore, to get the abstract idea accepted and to discuss later what it represents in practice. In this context, some go further and refer to European Union experience, claiming that competition law was initially introduced there without any developed sense of what was involved, leaving not only its details, but also its basic form for later development. ${ }^{19}$

Although this strategy is often used in multilateral negotiations, it may not be appropriate in the case of competition law at the WTO. It assumes that keeping the project vague will allow all participants to agree to support it because they will imagine the introduction of a form of competition law that they support or at least could accept. Here that assumption is highly questionable. The parties may well imagine the opposite. The assumption can be expected to hold only where at least one of two conditions is met. Either the parties must believe that the project will have no significant consequences for their interests or they must be confident that they can predict roughly what the potential consequences of introducing a competition law would be for them. Neither of these conditions is met here. First, the potential for competition law to affect a wide range of interests among members is high, so each member must expect potentially significant consequences from the introduction of such a regime. Second, the differences in forms of competition law and the potential consequences of choosing and implementing them are poorly known and understood, so there is little basis for a member to have confidence in predictions about what such a regime would mean for its interests. Moreover, it is precisely the lack of confidence in the current WTO decision making processes that is a cause for concern by many members, and thus they are unlikely to have confidence

10 This claim is misleading. The introduction of competition law ideas into the Treaty of Rome was based on well-developed ideas of the basic form such a competition law could be expected to take. These ideas derived primarily from US and German thought and experience and thus were not widely known in some countries. It was clear, however, that Germans would initially be entrusted by the other signatory states with taking the lead in developing competition law within the then 'common market,' and this is what occurred. For discussion, see David J. Gerber, Law and Competition in Teventieth Century Europe: Protecring Prometheus (New York and Oxford, England: Clarendon Press, 1998, 2001) 232-65; 346-84. 
that they could significantly influence decisions regarding implementation of the idea. As a result, in the absence of greater clarity about the forms, possibilities and variations of competition law, each member is likely to project a concept of competition law. that would cause the greatest harm to its interests. Its representatives are virtually impelled to do so as a means of minimizing damage to the interests they represent.

\section{A. Differing conceptions of competition law}

Under these circumstances, it is difficult to expect the WTO's membership to support inclusion of a competition law regime. Even if it were included, it is difficult to imagine it becoming effective. In order to make such a project both possible and effective, it is important to identify the range of conceptions of competition law and on that basis to develop a concept of competition law that is appropriate for inclusion in the WTO. ${ }^{20}$

Identifying the range of meanings of 'competition law' minimizes misunderstandings about the nature of the project and is likely to increase the alignment of expectations regarding it. The objective is to provide a minimum degree of content about what the project of including competition law in the WTO might entail. I do not suggest, of course, that the details need to be worked out in advance, but the basic conception - the basic outlines of goals and methods - should be clarified so that decision makers at least know what they are being asked to support and, perhaps later, implement.

The first step in clarifying the picture is to distinguish 'competition law' from 'unfair competition law', because inconsistencies in use of the terms and their analogues in languages other than English often cause confusion even at this basic level. In the context of some national legal regimes, the term 'competition law' (or its cognates) includes two distinct legal regimes. One protects competitors against unfair competition; the other protects the process of competition from restraints. Unfair competition law regimes contain principles and procedures that entitle a private party to take legal action against an economic actor who has engaged in conduct that is deemed 'unfair' and thereby harmed the economic interests of the plaintiff. Unfair competition law is often understood as part of or closely related to tort law, and it is specifically intended to protect private economic interests. This is NOT what is contemplated in the context of the WTO.

'Competition law' in the narrower sense is a fundamentally different conception, and it is this use of the term that is relevant in the context of

${ }^{20}$ For discussion of the range of differences among existing systems and the issues involved in comparing and relating them to each other, see David J. Gerber, 'Comparative Antitrust Law', in Mathias Reimann and Reinhold Zimmerman (eds), Oxford Handbook of Comparative Law (Oxford: Oxford UP, 2006) 1193. For further discussion of how competition laws can relate to each other in the context of globalization, see David J. Gerber, 'Competition', above $\mathrm{n} 10$. 
the WTO. At its most basic, 'competition law' involves protection of the process of competition. In the US and increasingly in other parts of the world, the term 'antitrust law' is applied to such regimes. Here the objective is to protect the competitive process against restraints on the process. It seeks to eliminate obstacles to the effective functioning of markets in order to allow the competitive process to provide to the fullest extent possible the economic benefits that effectively functioning markets can provide. The primary beneficiary of such a regime is the public. In some national regimes, private parties may be entitled to sue for violations of competition law and thus pursue their own private interest, but the goal of the legal regime is to provide a public good.

Even within this form of competition law, however, there is significant variation in goals, perspectives, methods, institutions and operative concepts. ${ }^{21}$ In short, there is no single model of competition law. I will here note only two fields of difference among many.

One area of difference involves the goals of competition law. The narrowest view of competition law's goals is currently found in US antitrust law, where the generally accepted goal is 'consumer welfare'. As used in this context, this is a technical term derived from economic science, specifically, from neo-classical economics. The basic standard for applying the law is whether conduct has increased price above a competitive level or is likely to have that effect. This goal requires for its application significant reliance on economists and economic science. It has been developed over the last three decades, primarily in the United States, where it has now become the orthodox understanding of what competition law's goals should be. ${ }^{22}$

Competition law can also have other goals. In the United States, for example, the current narrow view of antitrust's goals is relatively new. For decades before the 1970 s the courts developed the goals of antitrust on an ad hoc basis. They included, for example, economic goals defined in terms of the structure of markets. Here the concern was that particular market structures, especially those dominated by small numbers of firms with large shares of the market, were in themselves a restraint on competition, and antitrust law should be used to prevent the creation and strengthening of those positions. Antitrust was also seen at times as a tool for preventing dominant firms from using their economic power to harm or eliminate small and medium-sized enterprises. It was believed that such practices were indirectly harming society itself by eliminating the opportunities for smaller firms to compete and for local firms to remain independent. The courts also considered political goals. Here competition was protected in order to

21 See, e.g. Juergen Basedow (ed.), Limits and Control of Competition suith a Vivw to Harmonization (The Hague: Kluwer Law Internarional, 2002) and Roger Zaech (ed.), Towards WTO Competition Rules (The Hague: Kluwer Law International, 1999).

22 For discussion of this evolution, see Gerber, 'Competition', above n 10, at 512-22. 
protect the political process from the undue influence of very large corporations. This mixture of goals was not always internally consistent, and dissatisfaction with this inconsistency is one of the factors that have led to a radical narrowing of antitrust's goals during the last three decades.

In Europe and elsewhere, the goals of competition law often also exhibit extensive variety. For example, concern with the power of large firms to distort competition has been a major focus of competition law in Europe. This has supported the idea that dominant firms are subject to special scrutiny and owe a 'special duty' not to use their power to distort competition: In addition, the European Union's competition law goals have included the integration of national markets. Here the idea is that in order to achieve a single and undistorted market; it is necessary to prevent powerful firms or groups of firms from impeding the process of economic integration. In developing countries, an objective of competition law is sometimes to protect domestic firms by seeking to prevent powerful foreign firms from using their power or size in ways that impede the development of domestic firms. In some countries, there are also special features of competition laws based on unique circumstances. In South Africa; for example, competition law has included special provisions to protect firms owned and managed by those who suffered from apartheid.

A second range of difference relates to competition law methods - i.e. the means of implementing normative goals. There are two basic approaches. In the United States, private enforcement has always played an important role in implementing antitrust law, and in many ways the development of US antitrust law has been colored and shaped by this heavy reliance on private litigation. In most of the rest of the world, however, enforcement relies predominantly or exclusively on administrative decision making. This reliance influences all aspects of thinking about competition law, including, inter alia, procedures, the forms of information available to decision makers, the political incentives to take enforcement action and the norms of competition law themselves.

\section{B. Toward a WTO-compatible competition law}

Given this level of variation in the aims and methods of competition law, it will be necessary to make choices about the general characteristics of a competition law that might be considered for introduction into the WTO. Broad-based support for choices of this kind is likely to require development of a form of competition law that is specifically designed to fit the needs and objectives of the WTO. Here conceptions of 'community' can be expected to play a major role. In order for all categories of members to support a competition law project for the WTO, the project should be consistent with the more community-oriented conception of the WTO outlined above. 
Many factors may be involved in developing such a conception of competition law. I here suggest several elements that would support such a conception and facilitate its introduction and implementation. They are intended to be consistent with and to foster an enriched form of community within the WTO.

One involves the general conception of competition law. Critical to success of the project will be establishing the perception that the regime is a 'shared resource' in whose success all members have a stake and from which each expects to derive significant net benefits for itself. ${ }^{23}$ This assumes that all members view improved efficiency on global markets as beneficial to their own interests. Most, if not all, members can be expected to see some benefits in such improved efficiency, but their view of the net benefits is likely to depend on the expected costs to them. If a Member State expects the operation of the system to lead to forms and patterns of economic development that it considers politically unacceptable, those costs will weigh heavily in that member's assessment of the net value of the project.

On a more general level, willingness to support a competition law regime will depend on how the expected benefits of the system are likely to be distributed. If such a regime is expected systematically to favor one group or set of interests over others, competition law will for many members appear not be a shared resource, but rather a tool for the attainment or maintenance of advantages by the favored groups. The success of a competition law project at the WTO will depend, therefore, on creating justified expectations that the net benefits to members will be widely and relatively evenly distributed. A form of competition law that serves primarily to achieve market access for developed country companies is not likely to be acceptable. ${ }^{24}$

A second factor involves the goals of a WTO competition law regime. Given the significant variations among goals in existing and past competition law systems, the choice of goals to guide decision making is of central importance. The relatively narrow economic efficiency goal of the current US system has much to commend it for many purposes and in many contexts, but the diversity of needs within the WTO may call for a degree of flexibility in the goal structure that would include developmental goals. This will require serious and creative thought in defining the relationships among the goals themselves and relating them to the objectives of the WTO as an institution.

${ }^{23}$ For discussion of related issues involving competition law and the WTO as a 'public good, see Josef Drexl, 'International Competition Policy after Cancun: Placing a Singapore Issue on the WTO Development Agenda', 27 World Comperition 419 (2004).

2-t For discussion of the relationship between market access issues and competition law, see gen. Eleanor Fox, 'Toward World Antitrust and Market Access', 91 American Journal of International Law 1 (1997) and Daniel K. Tarullo, Norms and Institutions in Global Competition Policy', 94 American Journal of International Lav 478 (2000). 
An important element here is likely to be the temporal perspective of the goals. The WTO context is likely to require a longer-term, developmental dimension. The goal of competition law at the WTO level would enhance the economic welfare of national economies at significantly different stages of economic development, and thus an effective competition law would have to take that longer-term perspective into account. A goal structure that focuses exclusively on the short-run and immediate effects of anticompetitive conduct may have limited attractiveness.

At least as important as defining the goals of such a competition law regime is the task of developing its methods. This third factor is institutional and procedural. Among existing competition law systems, differences in the way decisions are made and goals implemented are in many ways more important than differences in the goals and articulated norms themselves. In order for competition law to be an effective part of the WTO, the institutional framework must generate confidence that an enriched form of community, as discussed above, would actually be built into the fundamental decision-making processes that implement competition law.

In shaping a competition law regime that would be appropriate for this context, several factors are likely to play key roles. First, the decisional structure should assure a high degree of independence for the decisionmakers. The history of competition law everywhere highlights the risks of interference from both public and private actors and repeatedly shows that if such independence is not provided, competition law is unlikely to flourish. Second, the decision-making institutions must include and interrelate solid expertise in several areas, including national and regional competition law experience, economics, including, in particular, international development economics, and international relations. Without such a foundation of expertise, decisions are not likely to achieve the status and consistency that will be necessary for the success of a competition law project. ${ }^{25}$ And, third, the institutions and procedures should not be dominated by individuals, thought patterns or modes of operation from one country or group of countries. While there will be much benefit in using experience accumulated at the national and regional levels, competition law institutions that do not reflect the interests, values and problems of all categories of WTO members are not likely to engender trust on the part of those whose interests and concerns are not represented. In short, for them such a competition law would have little to do with 'community'.

The process of designing a competition law regime for the WTO should draw on existing models and experience at the national and European levels, but it is unlikely that any single current competition law system could be

${ }^{25}$ For in-depth analysis of current issues in WTO decision making, see William J. Davey, Enforcing World Trade Rules: Essays on WTO Dispute Settlement and GATT Obligations (London: Cameron May, 2006). 
transplanted effectively to the WTO context. The needs and politica situation of the organization differ greatly from anything that has yet bee tried. It is thus necessary to think afresh about competition law rather thas merely assume that some existing form would be appropriate for the WTO

Fortunately, some foundations for pursuing such a goal are already presen within the institutions of the WTO. The Working Group on Trade anc Competition that was established in the late 1990s in preparation for thi Doha Round brought together specialists and gathered information fron many sources. This information and experience could be used as a base fo: developing a WTO-specific conception of competition law. Moreover, thi Trade Policy Review Mechanism has a broad mandate for developin policies that might relate to trade, and it is well-positioned to contribute ti the development of an appropriate form of competition law.

\section{CONCLUDING COMMENTS}

This brief essay has identified two main obstacles to the inclusion $\circ$ competition law in the WTO-(i) a perceived lack of 'community' in the norms and operations of the WTO and (ii) uncertainty about the form anc potential consequences of the competition law that might be introduced. Ths inclusion of competition law as an effective part of the WTO is likely tc require that substantial progress be made in eliminating both obstacles.

The obstacles are imposing. They relate to basic perceptions anc conceptions of the WTO and the processes by which decisions are madt within it. Reducing such obstacles will, therefore, require reconceiving anc re-imagining the relationship between competition law and the WTO A WTO that operates primarily as a forum for negotiating market acces: rights is likely to require modification if it is to support an effective compe. tition law regime. It is likely that the success of such a modification wil. depend on its capacity to generate trust among all categories of WTC members. It is likely also to include development of a conception of com. petition law that treats global competition as a resource to be shared by all

The image of 'community' within the WTO context may long-or ever: permanently - remain a vague ideal to which reference is occasionally made: but which has no operative role in WTO decision making. If it is to be more than that, competition law may serve as both a metric of progress and $\varepsilon$ mechanism of support, and the benefits are likely to reach far beyond the institutions of the WTO. 